\title{
The Use of Contextual Teaching and Learning to Teach Reading Comprehension Viewed from Students' Locus of Control
}

\author{
Sunarti Sunarti, Rani Herning Puspita \\ Faculty of Education, English Department Universitas Muhammadiyah Kalimantan Timur, Samarinda, Indonesia
}

Email address:

sun377@umkt.ac.id (S. Sunarti)

\section{To cite this article:}

Sunarti Sunarti, Rani Herning Puspita. The Use of Contextual Teaching and Learning to Teach Reading Comprehension Viewed from Students' Locus of Control. Teacher Education and Curriculum Studies. Vol. 4, No. 4, 2019, pp. 58-64. doi: 10.11648/j.tecs.20190404.11

Received: November 1, 2019; Accepted: November 26, 2019; Published: December 6, 2019

\begin{abstract}
The aims of this study are to investigate: (1) if CTL is more effective than grammar-translation method to teach reading comprehension; (2) if the students having high locus of control have better reading mastery than those having low locus of control; and (3) if interaction between methods used and students' locus of control is availavle. The research was conducted at University of Muhammadiyah Kalimantan Timur. The samples were from two classes, cluster random sampling technique was used. Each class was divided into two groups (the students who have high and low locus of control) in experiment and control class. The techniques used to collect the data were questionnaire and reading comprehension test. The two instruments were tried out to get valid and reliable items. The data were analyzed by using multifactor analysis of ANOVA 2x2 and Tuckey test. The research findings: (1) CTL is more effective than GTM to teach reading comprehension, the result from ANOVA shows that $\mathrm{F}_{\mathrm{o}}$ is higher than $\mathrm{F}_{t}$ or $\mathrm{F}_{\mathrm{o}}>\mathrm{F}_{\mathrm{t}}$; (2) the reading comprehension of the students who have high locus of control is better than that of those who have low locus of control, the result from ANOVA shows that Fo is higher than Ft or $\mathrm{F}_{\mathrm{o}}>\mathrm{F}_{\mathrm{t}}$.; and (3) there is an interaction between teaching methods and Locus of control for teaching reading. It's concluded that teaching methods had a strong influence on students' reading comprehension.
\end{abstract}

Keywords: Contextual Teaching and Learning, Reading, Students' Locus of Control, Grammar Traslation Method

\section{Introduction}

The Researchers found problems with the reading ability of nursing students. Through the lecturer interviewed, it was found that many students did not like to read and seem difficult to get text messages when they joined in the teaching and learning process. Several causes of students' difficulties in reading comprehension. Unknown ways of reading fluently is one causes of students' difficulty. They are passive in reading activities. They have a low vocabulary that influences their interest in reading texts. Therefore, their reading test results are not good. It is suspected that the method used by the teacher is not appropriate. The method used by the teacher is considered less effective in improving students' reading comprehension [1].

Based on the description above, the formulation of the problem in this study is as follows: (1) Why do students have low English text comprehension?; (2) Does the method used by the teacher affect the ability of students to understand reading material?; (3) Does the teacher create real situations in the classroom that support teaching and learning?; (4) Does the teaching method using Contextual Teaching and Learning (CTL) provide optimal learning outcomes in teaching reading?; (5) Does the translation method (grammar-translation method) provide optimal results in teaching reading?; (6) Does the student locus of control affect reading comprehension?.

The Researchers are interested in conducting experimental research using the Contextual teaching and Learning (CTL) method. Based on the theory of contextual learning, If new information or knowledge are processed and absorbed into students' minds then the students try to find the similar cases to the real life in their environment. This approach argues that someone's mind influenced the significance of word or sentence by the environment where they belong. CTL is a learning method with an approach which connects 
knowledge with the context of everyday life. Significant impact of this approach is expected that the information received is not only stored in short-term memory, which is easily forgotten, but can be stored in long-term memory so that it will be lived and applied in the real world.

In this case the researcher will use a control group to observe the effectiveness of the method used. This research used the Grammar Translation Method (GTM). GTM is a language teaching method that makes it possible to use native languages in learning target language (English) or the language used in classrooms is mostly the students' native language and the teacher is the authority in the class. There is no or less interaction between students and between teacher and students. Activities in this method memorize the vocabulary and grammar which are taught deductively.

In this study, student learning activities and learning abilities will be viewed from students' locus of control. Locus of control is a term that refers to an individual's perception of personal control, specifically relating to control over important results. Locus of control refers to a person's beliefs about how an individual's efforts in achieving the desired results [2]. The function of student locus of control is to assess whether the learning process is successful or not. The objectives of this study are: (1) To find out whether CTL is more effective than GTM for teaching reading to nursing students; (2) To find out whether students who have high locus of control have better reading skills than students who have low locus of control in nursing students; (3) To find out whether there is an interaction between teaching methods with locus of control in nursing students.

The author hopes this research will make a useful contribution to the researchers themselves: By conducting this research, the researcher is able to increase the knowledge of how reading comprehension is taught to students and how to measure their understanding of reading texts, students: This is able to provide input for students so that they are able to understand reading texts well, and also provide motivation to learn English specifically for Reading comprehension lessons, English language educators: The author hopes the results of this study provide the benefits of at least providing information to the English teacher / instructor in using the CTL method in student reading learning activities. Furthermore, other researchers: This research is able to provide information that there are effective methods for teaching reading comprehension and developing similar research in different subjects. This research can be used as a reference for other researchers.

Reading is an interactive process to build meaning from printed text. In other words, it can be said that reading is an active process for interpreting and developing ideas or complete messages from a text. Reading is not only seeing or reading what is written but also understanding the contents of the reading so that readers get knowledge and information from the reading. Some reading components put forward by experts, such as understanding main ideas, supporting ideas, vocabulary, and grammar, make teachers must be careful in applying methods in teaching English, especially reading.
Reading is a process to determine, what the brain, emotions and beliefs of readers bring to reading. This means that reading is the reader's way of interpreting printed words [3]. Reading comprehension emphasizes two things namely what the writer has in writing and the reader's ability to use their background knowledge and thinking ability to understand the text [4]. It can be said that reading comprehension not only "reads" the text directly, but also gets something out of the text. When a student who is struggling to read words and focuses so hard only speaks the words correctly, all their cognitive abilities are put into the right words with the right pronunciation but very little effort to make sense of what is being read.

"Reading is the act of constructing meaning while transacting with text. just as we use information stored in schemata to understand and interact with the world around us, so do we use this knowledge to make sense of print "[5]. Based on this opinion it can be seen that reading is an act of constructing meaning when transacting with text. Just as we use information stored in schemata to understand and interact with the world around us, so we use this knowledge to understand printed words. Reading when viewed based on the skills of readers is classified into reading comprehension, extensive reading, and speed reading. While practically, reading can also be divided into oral reading and reading silently, [6].

It can be concluded that reading not only involves the text and the reader as physical entities that are needed in the reading process but also the interactions between them that occur when the reader tries to find the meaning of the text. Reading skills include reducing the meaning of unknown lexical items, identifying key points, understanding explicitly stated information, and extracting important points into a summary. Interpreting reading is a cognitive process to get meaning (messages) from the text, which involves activating prior knowledge (schemata theory), guessing, and predicting.

Reading viewed based on the skills of readers is classified into reading comprehension, extensive reading, and speed reading. It is revealed that reading comprehension is a complex intellectual process that includes two main abilities, namely mastery of word meaning and the ability to think about verbal concepts [7].

Understanding of reading material does not only depend on what is contained in the reading, but also depends on previous knowledge that has been read by the reader. The process by which the reader actively builds his understanding of the reading. [7] states that reading is essentially a process of building understanding of written discourse. This process occurs by pairing or connecting schemes of knowledge and experiences that have been previously owned with the content of information in the discourse so that it forms an understanding of the discourse that is read. Smith states that reading comprehension is an activity carried out by the reader to link new information with old information with a view to gaining new knowledge [7]. Besides connecting information and gaining new knowledge, activities carried out by readers in understanding reading material can be 
classified into literal understanding, interpretation of interpretation, critical understanding, and creative understanding.

Turner reveals that a reader is expected to understand the material well when obtaining the following: a) Knowing the words or sentences in the reading and knowing its meaning; b) To know the meaning of the experience that is gained by the meaning of the reading; c) Understand the whole meaning contextually; d) Consider the value of reading content based on reading comprehension [7]. There are three basic things in reading comprehension, namely, the knowledge and experience you already have on the topic, linking your knowledge and experience with the text to be read, and the process of acquiring meaning according to what you already have.

Contextual learning was first proposed in America by John Dewey, in 1916. Dewey proposed a curriculum and teaching methodology that was associated with students' interests and experiences [8]. Blanchard, Berns and Ericson suggested that Contextual Teaching and Learning (CTL) is a concept of learning and teaching that helps teachers link between the material being studied with the real world situation of students and encourages students to make connections between knowledge possessed by their application in their lives as family members, citizens and workers [9]. The application of CTL is expected to be able to build students' understanding of the material that has been taught because the student experiences the material in the real world, so that he will have a strong memory for the material he gets. Whereas Johnson defines CTL more simply, contextual learning that allows students to connect the contents of the material with the context of everyday life to find meaning [10].

The components of the application of the learning process using CTL are as follows: (a) Constructivism: Constructivism is the process of building or compiling new knowledge in students' cognitive structures based on experience. According to Mark Baldawin's constructivist philosophy and deepened by Jean Piaget, the knowledge is formed not only from objects, but also from the ability of individuals as subjects to capture every object they observe. The foundation of this learning is that students build their own understanding from new experiences based on initial knowledge. Learning must be packaged into a process of "constructing" rather than receiving knowledge. Therefore the teacher must facilitate the process by: 1) Making knowledge meaningful and relevant for students, 2) Giving students the opportunity to find and determine their own ideas, 3) Awaken students to apply their own strategies in learning; (b) Inquiry: Finding (Inquiry) is a learning process based on achievement and discovery through a systematic thought process. Knowledge is not a number of facts that result from remembering, but results from the process of discovering itself. In the inquiry model can be done through a number of systematic steps, namely: 1) Formulating the problem, 2) Proposing a hypothesis, 3) Collecting data, 4) Testing a hypothesis based on data collected, 5) Making conclusions; (c) Learning Community: The concept of learning communities in CTL suggests that learning outcomes are obtained through collaboration with others. This cooperation can be carried out in various forms both in formal study groups and in naturally occurring environments. Learning outcomes can be obtained from the results of sharing with others, between friends or between groups; who already know tell those who don't know or who have experience sharing their experiences with others; (d) Modeling: Modeling is a learning process by demonstrating something as an example that can be emulated by every student. The modeling process is not limited to teachers, but can also utilize students who are considered to have abilities. Modeling is a principle that is quite important in learning CTL because through modeling students can avoid theoretical - abstract learning that can enable verbalism. The teacher or other experts can be a model for students in learning; (e) Reflection: Reflection is a way of thinking about what has just been learned or thinking back about what has been done in the past. Reflection is a response to events, activities, or experiences that have just been received. Through the process of reflection, the learning experience will be included in the cognitive structure of students which will eventually become part of the knowledge they have. Meaningful knowledge is obtained from the process, so reflection is needed at the end of the learning process; ( $f$ ) Authentic Assessment: Authentic assessment is a process carried out by the teacher to collect information about the learning progress undertaken by students. This assessment is conducted to find out whether students really learn or not; whether student learning experiences have a positive influence on the development of both intellectual and mental students. Authentic assessment is carried out in an integrated manner with the learning process. This assessment is carried out continuously throughout the learning activities take place. Therefore, the emphasis is directed on the learning process not on learning outcomes.

Grammar-Translation Method (GTM) is a language teaching that was developed during the 18th and 19th centuries in Germany. Also called the classical method, where traditional methods are adopted to teach classical, Latin and Greek. Kim concluded that grammar is a traditional translation and an ancient teaching method. Generally, classical languages are taught by reading and translating text extracted from classical literature, which is similar to the grammar-translation method.

Teaching instructions using GTM are provided in the native language. "There is little use of the target language for communication. The focus is on grammatical parsing, that is, the form and inflection of words. The typical exercise is to translate sentences from the target language into mother tongue (or vice versa). The result of this approach is usually the inability of students to use language for communication. The teacher does not need to be able to speak the target language fluently [11]." In addition to these principles, [12] in grammar translation methods, both teachers and students have traditional roles. The teacher has authority in the 
classroom and students tend to follow the teacher. In addition, students learn deductive grammar rules; that is, first they provide grammar rules by example, second they are asked to memorize the rules, and finally, they are instructed to use the rules in other examples. Under the instruction of the grammar method, students were taught systematic grammatical rules [13].

Locus of control is a term that refers to perceptions about personal control, specifically related to control over important results. Locus of control refers to a person's beliefs about how an individual's efforts in achieving the desired results [2]. While [14] explains that the Locus of Control is the level where individuals believe that they are determinants of their own destiny. Furthermore, [15] the definition of locus of control is a source of confidence possessed by individuals in controlling events that occur both from themselves or from outside themselves.

Based on the explanation above, it can be concluded that the locus of control is the degree to which an individual's belief in the source of causes of events that occur in his life, whether his success, achievement and failure in his life are controlled by his behavior (internal factors) or all events what happens in his life in the form of achievement, failure and success is controlled by other forces, such as the influence of other people in power, opportunity, luck and fate (external factors).

Internal control refers to the perception of events both positive and negative as a consequence of one's own actions or actions and is under his control [16]. Furthermore, Internal locus of control refers to the perception, both positive and negative, occur as a consequence of one's own actions and under self-control [17], while external locus of control refers to the belief that an event has no direct relationship with actions by oneself and is out of his control. [18] Internal locus of control is associated with the adoption of a deep or strategic learning approach.

Meanwhile, [18] Students with external locus of control maintain a passive attitude towards their grades, assigning responsibility for their performance to others rather than accepting responsibility for themselves. Students who have an external locus-of-control believe that their actions will not affect the final results, they tend to be frustrated and anxious [15]. External locus of control is characterized by the belief that the consequences are the result of fate, fortune, or someone else who is strong (http://www.iranpa.org.pdf). According to Rotter, individuals of external locus of control believe that "reinforcements are not under their personal control but more under the control of others who are strong, fortune, opportunity, fate, etc." [15]. Another definition put forward by Cassidy and Eachus that the external locus of control is associated with apathetic learning approaches [15].

Based on the explanation above it can be concluded that the internal locus of control is an individual's belief that the one who controls fate is himself. Whereas external locus of control is an individual's belief that his destiny is controlled by something outside his control.

\section{Research Methodology}

In this research, the writer chose the experimental research method because this research was related to the effect of teaching methods as the independent variable, and Locus of control as the attribute variable in teaching reading comprehension for nursing class at Universitas Muhammadiyah Kalimantan Timur. The teaching methods used in this study were Contextual Teaching and Learning and Grammar Translation Method. These two different methods were applied differently for the groups of the students. In this case, a group of students taught by Contextual Teaching and Learning was used as experimental group and a group of students taught by Grammar Translation Method was used as control group. Then, it was a simple factorial design because this research consisted of two independent variables, Contextual Teaching and Learning and Grammar Translation Method, one attribute variable, Locus of Control (high and low); and one dependent variable, reading comprehension.

This research was conducted in the Nursing class at University Muhammadiyah Kalimantan Timur. The research population is undergraduate students of Nursing at University Muhammadiyah Kalimantan Timur, there are 100 students. Total sample used in this research is 60 students of nursing class. In this study, the authors used Cluster Random Sampling to get samples from the population. To determine the sample into an experimental and control class, the authors chose it randomly. To classify students in each class into classes of high and low Locus of Control researchers used the median Locus of Control score.

In this research the writer used test to get the score of reading comprehension and questionnaire to get student's locus of control. Meanwhile, data of reading comprehension, the writer used multiple choices. Meanwhile, the writer used questionnaire to get the data of students' locus of control. Furthermore, questionnaire is a tool of collecting data by giving written questions which will be answered by respondents. The researcher gave a sheet of questionnaire dealing with student's locus of control by alternative answer.

In order to identify the mean, median, mode, and standard deviation of reading test score the writer used a descriptive statistics. While, in testing the hypothesis is used Inferential analysis. Before testing the hypothesis, it is necessary to know the normality and homogeneity. After that, she tested the hypothesis by using Multifactor Analysis of Variance or ANOVA 2X2. It is used to find out the difference between columns and row. Besides ANOVA, the writer used Tukey Test to identify the significant difference between groups.

\section{Research Findings and Discussion}

\subsection{Anova Test}

Hypothesis testing done after the data are normal and homogeneous. The data analysis is done by using multifactor analysis of variance $2 \times 2$. there is a significant difference and an interaction when Ho is rejected if Fo $>$ Ft. Then 
analysis data is continued using Tukey test. The analysis of data is aimed: (1) To know whether CTL is more effective than GTM for teaching reading to nursing students; (2) To know whether students having high locus of control have better reading skills than students having low locus of control in nursing students; (3) To know if there is an interaction between teaching methods with locus of control in nursing students.

The multifactor analysis of variance $2 \times 2$ and Tukey test are described below:

Table 1. Summary of a $2 \times 2$ Multifactor Analysis of Variance.

\begin{tabular}{llllll}
\hline Source of variance & SS & DF & MS & $\mathbf{F}_{\mathbf{0}}$ & $\mathbf{F}_{\mathbf{t}(.05)}$ \\
\hline Between columns (Teaching methods) & 79.35 & 1 & 79.35 & 13.35 & 7.31 \\
Between rows (Locus of control) & 58.01667 & 1 & 58.01667 & 9.76 \\
Columns by rows (Interaction) & 432.0167 & 1 & 432.0167 & 72.69 & \\
Between groups & 569.3833 & 3 & 189.7944 & \\
Within groups & 332.8 & 56 & 5.942857 & \\
Total & 902.1833 & 59 & & \\
\hline
\end{tabular}

The conclusion of the table above, are as follows:

Firstly, between the columns Fo $(13,352)$ is higher than $\mathrm{Ft}$ at at the level of significance $(\alpha)=0.05$ (7.31) and the significant level $(\alpha)=0.01$ (4.2), the difference between methods is significant. Because the mean of students who taught using CTL (28.27) is higher than those who taught using GTM (25.97), it can be assumed that CTL is more effective than GTM for teaching reading comprehension.

Secondly, F between locus of control $(9,762)$ is higher than Ft at significance level $(\alpha)=0.05(7.31)$ and at significance level $(\alpha)=0.01$ (4.2), the comparison between row is significant. Because the mean students who have high locus of control is 28.1 and the average of students' value who have low locus of control is 26.13, it can be said students who have high locus of control got better reading comprehension than those having low locus of control.

Thirdly, Because Finteraction between groups (72.695) is higher than Ft (7.31) at the significance level $(\alpha)=0.05$ and at $(\alpha)=0.01$ (4.02), methods used and students' locus of control indicates interaction, the effect of teaching methods depends on the level of locus of control.

\subsection{Tuckey Test}

After using $2 \times 2$ analysis of variance, researchers analyzed the data using Tuckey test. Tuckey test was conducted to find the differences between groups.

Firstly, the value qo of methods is 5.17 and the value qt of Tukey's table at significance level $\alpha=0.05$ is 2.89 and $\alpha=$ 0.01 (3.89). Because qo $>$ qt or qo (5.17) $>$ qt (.05) (2.89), Ho is rejected and it can be concluded that there is significant difference on the students' reading comprehension between those who taught using CTL and those who taught using GTM. Meanwhile, based on the calculation result, the average of the students using CTL (28.27) is higher than those using GTM (25.97). It can be assumed CTL is more effective than GTM to teach reading.

Table 2. Result of Tuckey's Test.

\begin{tabular}{lllll}
\hline \multirow{2}{*}{ Cells } & \multirow{q_{0}}{*}{} & $\mathbf{q}_{\mathbf{t}}$ & & Status \\
\cline { 3 - 4 } & & $\mathbf{0 . 0 5}$ & $\mathbf{0 . 0 1}$ & \\
\hline $\mathrm{A}_{1}-\mathrm{A}_{2}$ & 5.17 & 2.89 & 3.89 & Significant \\
$\mathrm{B}_{1}-\mathrm{B}_{2}$ & 4.42 & 2.89 & 3.89 & Significant \\
$\mathrm{A}_{1} \mathrm{~B}_{1}-\mathrm{A}_{2} \mathrm{~B}_{1}$ & 12.18 & 3.01 & 4.17 & Significant \\
$\mathrm{A}_{1} \mathrm{~B} 2-\mathrm{A}_{2} \mathrm{~B}_{2}$ & 4.87 & 3.01 & 4.17 & Significant \\
\hline
\end{tabular}

Secondly, Because qo between row B1 and B2 (4.42) is higher than qt at significance level $(\alpha)=0.05$ (2.89) and $\alpha=$ 0.01 (3.89), Ho is rejected and the students who have high locus of control significantly different from those who have low locus of control in reading comprehension. Because the average of students who have high locus of control (28.1) is higher than those having low locus of control (26.13), it can be assumed the students who have high locus of control got better reading comprehension than those who have low locus of control.

Thirdly, The value of qo, A1B1 and A2B1 is (12.18) and the value of qt of Tukey's table at significance level $(\alpha)=$ 0.05 (3.01) and $\alpha=0.01$ (4.17). Because qo $>$ qt or qo $(12.18)>$ qt $(.05)$ (3.01), Ho is rejected and it can be assumed using CTL significantly different from GTM to teach reading comprehension to the students having high locus of control. Moreover, according to the calculation the average value, they are A1B1 (31.93) is higher than the mean scores of A2B1 (24.06) so that it can be assumed CTL is more effective than GTM to teach reading of students who have high Locus of control.

Fourthly, The value of qo between cells A1B2 and A2B2 is (4.87) and value qt of Tuckey's table at significance level $(\alpha)=0.05$ (3.01) and $\alpha=0.01$ (4.17). Because qo $>$ qt or qo $(4.87)>$ qt $(.05)(3.01)$, Ho is rejected and the average value A1B2 (24.27) is higher than the mean scores of A2B2 (27.67) so It is assumed teaching reading using GTM for students who have low Locus of control is more effective than those having low Locus of control who are taught using CTL.

Fifthly, Based on the results of points 3 and 4, teaching reading using CTL method is more effective than GTM for students having high locus of control and students having low locus of control, GTM is more effective. It is assumed that interaction between methods used and locus of control in teaching reading comprehension is available, and based on the results of ANOVA (Fo> Ft) (72.69> 4.08), Ho is rejected and $\mathrm{H} 1$ which states that interaction of methods used and locus of control in teaching reading comprehension is available, accepted.

Relate to the finding, the explanations are as follows:

Firstly, in teaching reading comprehension by CTL method is more effective than GTM. 
In CTL the teacher connects the material given with the students daily live by dealing the students with it through constructivism, and then in teaching and learning process, in order to make students mastery the material easily the teacher let the students doing learning community. It also gives opportunities for students to understand the reading passage by the real experience. When the situation around them is created naturally, the students learn better. In this case, the students also become a model to other students. While, inquiry, the students possibly to search something in connecting to the material by themselves. In CTL, Questioning stage, the teacher plays role as motivator, provider and assessor of students' thinking ability. Then, as reflection, the teacher and the students review what they have learnt. The activity is done at post activity. Finally, teacher through authentic assessment describes the real competence of students.

Secondly, the higher reading comprehension of the students having high locus of control apparently exist than those who have low locus of control.

Students having high locus of control tend to be more active in teaching and learning process. Furthermore, they seem readily assume self-responsibility for their own performance and more active learners who do not rely on others to determine the outcome of their course experience. [19] state that students who believed that success was due to hard work had higher reading scores than did students who believed in luck. If students have high locus of control, of course, it will be easier for them to understand the reading materials and to obtain a good result.

Otherwise, students having locus of control believe that they have little control or power to affect personal outcomes. Therefore, they seem not interested to join in learning process. Students with low locus of control maintain a passive attitude toward their grades, assigning responsibility for their performance to others, such as the instructor, rather than accepting their responsibility. They become the followers in joining the reading class and passive in the class. Students with low locus of control do not see effort as related to achievement. [20], control of internal versus external refers to the level of someone expectation which reinforcement or an outcome of their behavior.

Thirdly, Interaction between methods used with locus of control is available.

Learning by using Contextual teaching and Learning method, students are actively involved in classroom interactions, students tend to show their curiosity about the reading material given at each stage of CTL. In addition, students show more motivation to understand the meaning of the subject matter by linking the material to the context of their daily lives. As explained in the reading comprehension, it is expected the students can identify main idea, find word references, find word meanings based on context, find explicit and implicit information and find communication functions, students who have high locus of control tend to be more interested in accepting responsibility for controlling their environment. They will be encouraged if the teacher gives them an opportunity to be actively involved in the teaching and learning process in finding solutions to reading problems, they are identifying key ideas, finding word references, finding meaning of words based on context, finding explicit and implicit information and finding communication functions.

The stages in CTL also encourage students to be involved throughout the learning process. Students will have critical and creative thinking through the process of searching, observing, observing, and analyzing [21]. Various forms of reading texts require students to find who the reader is, what was done, where and when the event occurred, how it could occur, conflict, resolution and marking. After students observe, investigate and finally analyze it.

On the other hand, GTM refers to the efforts to teach language through grammatical rules not emphasizing usage. Students who study foreign languages in the use of translation method (GTM) find difficulty to gain skills in acquiring the target language. Students who have a low locus of control tend to be passive, they tend to wait for instructions from the lecturer, without any initiative in receiving reading material. Students assume reading is completed by translating it into the target language, so that dependence on the English dictionary is very apparent in the use of GTM on reading comprehension.

Therefore, Interaction between methods used with locus of control in reading comprehension is available where students having high locus of control have a good understanding by CTL method instead the translation method (GTM) is suitable for students who having low locus of control.

\section{Conclusion}

According to the result of analysis, it is found as follows:

Firstly, CTL method is more effective than GTM to teach reading comprehension for nursing students.

Secondly, the higher reading comprehension appears on the students who have high Locus of Control than students who have low locus of control for nursing classes.

Thirdly, interaction between variables is available, teaching methods and the level of locus of control for reading activity in nursing class.

Fourthly, the result of research findings above, assumed that CTL proved as a method which is effective to teach reading comprehension for nursing classes.

In teaching using Contextual Teaching and Learning, however, any strengths and weaknesses. The weakness of contextual teaching and learning model is the teacher is expected to be able to manage the learning activity as well as possible so that the learning objectives that have been set can be achieved with a maximum. Meanwhile, some advantages using contextual teaching and learning method are: (1) learning activity becomes more meaningful and real, meaning that students are required to be able to capture the relationship between the learning experience in school and real life; (2) learning is able to cultivate the strengthening of the concept to the students more productive and because the 
contextual teaching and learning model embraces the flow of constructivism, which assumes the students can find and build their own knowledge. Through the philosophical foundation of constructivism students are expected to learn through "experience" rather than "memorize".

\section{References}

[1] Woolley, G. (2010) Developing reading comprehension: combining visual and verbal cognitive processes. Australian Journal of Language and Literacy, 33 (2), 108-125.

[2] Benson, Eric, \& Steele, G, Ric. 2005. Locus of Control: Encyclopedia of Human Development. SAGE Publications. 10 May 2010. Avalaible at: http://www.sageereference.com/humandevelopment/article_n382.html.

[3] Weaver, C. (2009). Reading Process Brief Edition of Reading Process and Practice. (L. Luedeke, Ed.). Ohio: Winthro Publisher, Inc.

[4] Sanchez, C. A., \& Goolsbee, J. Z. (2010). Character size and reading to remember from small displays. Computers \& Education, 55, 1056-1062.

[5] Ruddell, Martha Rapp. 2004. Teaching Content Reading and Writing. Wiley: USA.

[6] A, Aleka, dan H. Achmad H. P. 2010. Bahasa Indonesia untuk Perguruan Tinggi. Jakarta: Kencana Prenada Media Group.

[7] Sumadayo. (2011). Strategi dan teknik pembelajaran membaca (Learning technique and strategy in Reading. Yogyakrta: Graha Ilmu.

[8] Trianto. 2009. Mendesain Model Pembelajaran InovatifProgresif. Jakarta: Prenada.

[9] Komalasari, Kokom. 2011. Pembelajaran Kontekstual. Bandung: PT. Refika Aditama.

[10] Komalasari, Kokom. 2012. The Effect of Contextual Learning in Civic Education On Student' Character Development. Asia Pacific Journal of Educators and Education, Vol. 27 (Online), Http://apjee.usm.my/APJEE 27 2012/apjee27 2012 ART\%2 06\%20(87-103).pdf) diakses 9 Agustus 2018.
[11] Celce-Murcia, M. (2014). An overview of language teaching methods and approaches. In M.

[12] Larsen-Freeman, D., \& Anderson, M. (2011). Techniques and principles in language teaching (3rd ed.). New York, NY: Oxford University Press.

[13] Zhou and niu. 2015. Approaches to language teaching and Learning. Journal of Language Teaching and Research, Vol. 6, No. 4, pp. $798-802$.

[14] Robbins, Stephen P. \& Judge, Timothy A. (2008). Perilaku Organisasi. Jakarta: Salemba Empat.

[15] Duffy, K. G. \& Atwater, E. (2005). Psychology for Living: Adjustment, Growth, and Behavior Today. (ed. 8). New Jersey: Prentice Hall.

[16] Lefcourt. 1982. Locus of control : current trends in theory and research. Hillsdale NJ.

[17] Brownell, P. (October 1982b) "A field study examination of budgetary participation and locus of control", The Accounting Review, pp. 766-777.

[18] Grimes PW, Millea MJ \& Woodruff TW 2004. Grades Who's to blame? Student evaluation of teaching and locus of control. Journal of Economic Education, 35: 129-148. Available at http://www.proquest.com Accessed 10 October 2005.

[19] Berliner\& Gage. 1984. Educational Psychology. 3rd edition. Houghton Mifflin Company. All right reserved.

[20] Nowicki S, Duke MP. (2016: 70-147). Foundations of locus of control research. In: Infurna F, Reich JW, editors. Perceived control: theory, research, and practice in the first 50 years. New York, NY, USA: Oxford University Press; 2016. p. 147 70 .

[21] Nurdin \& Senduk, A. G. 2003. Pembelajaran Kontekstual dan Penerapannya dalam KBK Malang: Universitas. Negeri Malang. Media Group. 